\title{
Two cases of sodium azide poisoning by accidental ingestion of Isoton
}

\author{
S. G. N. RICHARDSON, C. GILES, AND C. H. J. SWAN \\ From the North Staffordshire Hospital Centre, Stoke-on-Trent
}

SYNOPSIS Accidental ingestion of sodium azide in $0.1 \%$ solution by a patient and a laboratory? technician in a haematological laboratory has demonstrated that very small quantities of sodium $\infty$ azide can give rise to toxic symptoms and that Isoton should be handled with care.

Sodium azide, which is known to be an explosive and also highly toxic substance, has long been used in the manufacture of detonators and also as a preservative of sera and other reagents in bacteriological laboratories. Since sodium azide is a constituent of Isoton, the diluting fluid for the Coulter Model S and other blood counters, it is now found in many haematological laboratories. The following account emphasizes the danger of sodium azide when used in laboratory reagents.

\section{Case Reports}

CASE 1

A 39-year-old man had been referred to the haematology department for a folic-acid absorption test. He had suffered from diarrhoea and was found to have macrocytosis and a low serum folate. For the test one ampoule of folic acid is diluted with 9 volumes of water, and a measured dose of the primary dilution is given to the patient in a glass of tap water. A junior laboratory technician had been in the habit of preparing the dilute folic-acid in distilled rather than tap water. On the day in question instead of distilled water she inadvertently used Isoton, which contains $0.1 \%$ of sodium azide. The patient drank the solution, which contained 50 to $60 \mathrm{mg}$ of sodium azide. Five minutes later he suddenly collapsed, briefly lost consciousness, and was incontinent of urine. When examined by one of us 10 minutes after the ingestion of Isoton he was pale and sweating and complained of feeling hot and nauseated and of a severe headache; his pulse rate was 120 per minute. Gastric lavage was performed and at this time his blood pressure was $100 / 60 \mathrm{~mm}$ $\mathrm{Hg}$. One hour after the event his pulse rate had fallen to 80 per minute, his blood pressure had risen to Received for publication 12 November 1974.
$120 / 85 \mathrm{mmHg}$, and his only symptom was persistent headache, which had disappeared by next morning. 3 When seen a week later he was well. Renal and liver $<$ function tests remained normal.

\section{CASE 2}

A recently enrolled junior laboratory technician, $a$ girl aged 18, was a further victim of the same accident. She 'liked the taste of folic acid' and took? a mouthful of the primary dilution of folic acid in

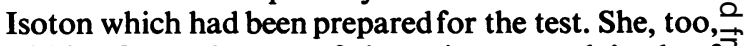
within five minutes of ingestion complained of headache, sweating, and faintness, which passed off rapidly. It is estimated that this technician took only? about 5 to $10 \mathrm{mg}$ of sodium azide.

\section{Discussion}

Sodium azide is a neutral stable salt of hydrazoico acid. Studies in vitro have shown it to inhibit cyto chrome oxidase and various other enzymes. In? experimental animals and in man it is a powerfuls hypotensive agent, increases the force and rate of을. the heart beat, and stimulates respiration. Largen doses produce convulsions and death. The $\mathrm{LD}_{50}$ o in mice is $27-37 \mathrm{mg} / \mathrm{kg}$ by the oral route (Graham, 1949; Sutton, 1963). Industrial poisoning is described NW by Gobbi (1967) in three workers who handledo sodium azide in bulk and who developed headacheso nausea, faintness, and transient hypotension; it waș uncertain in these cases whether the poison had been? inhaled or absorbed through the skin. According to Burger and Bauer (1965), a woman laboratory $\vec{P}$ technician accidentally swallowed about $150 \mathrm{mg}$ of sodium azide in a $10 \%$ solution and after five minutes developed dyspnoea, tachycardia, ando severe headache followed by diarrhoea and vomiting In this case sweating and weakness persisted for 10 
days. Suicide by ingestion of sodium azide by a man of 20 is described by Koźlicka-Gajdińska and Brzyski (1966); death occurred after 40 minutes; necropsy findings included cerebral and pulmonary oedema and inflammation of the oesophageal and gastric mucosae. Sodium azide, $130 \mathrm{mg}$, was recovered from the stomach and gut.

Our own patients were both young adults. One became unconscious and incontinent of urine after ingesting at most $60 \mathrm{mg}$ of sodium azide, and only 5 to $10 \mathrm{mg}$ caused distress and headache in the other. The incident has been reported in order to draw attention to the marked toxicity of sodium azide even in a dilute solution like Isoton.

As in the case of cyanide poisoning the only known antidote to sodium azide is dicobalt edetate. This drug must be given intravenously within minutes of exposure to the poison. It is, therefore, unlikely to be available on the rare occasions on which it is required.

\section{References}

Burger, E. and Bauer, H. M. (1965). Akuter Vergiftungsfall durch versehentliches Trinken von Natriumazidlösung. Archiv. Toxikol., 20, 279-283.

Gobbi, A. (1967). Tre casi di intossicazione da sodio-azide. Med. d. Lavoro, 58, 297-300.

Graham, J. D. P. (1949). Actions of sodium azide. Brit. J. Pharmacol., 4, 1-6.

Kožlicka-Gajdzińska, H. and Brzyski, J. (1966). A case of fatal intoxication with sodium azide. Archiv. Toxikol., 22. 160-163.

Sutton, W. L. (1963). Azides. In Industrial Hygiene and Toxicology, 2nd ed., edited by F. A. Patty, Vol. II, pp. 2208-2211. Interscience Publishers, New York and London. 